University of Wollongong

Research Online

Faculty of Informatics - Papers (Archive)

Faculty of Engineering and Information

Sciences

$1-1-2011$

\title{
Towards knowledge management in sports event management: Context analysis of Malaysian biannual games with CommonKADS
}

\author{
Azizul Rahman Abdul Ghaffar \\ University of Wollongong, arag865@uow.edu.au \\ Ghassan Beydoun \\ University of Wollongong, beydoun@uow.edu.au \\ Jun Shen \\ University of Wollongong, jshen@uow.edu.au \\ William Tibben \\ University of Wollongong, wjt@uow.edu.au
}

Follow this and additional works at: https://ro.uow.edu.au/infopapers

Part of the Physical Sciences and Mathematics Commons

\section{Recommended Citation}

Abdul Ghaffar, Azizul Rahman; Beydoun, Ghassan; Shen, Jun; and Tibben, William: Towards knowledge management in sports event management: Context analysis of Malaysian biannual games with CommonKADS 2011, 377-383.

https://ro.uow.edu.au/infopapers/1271

Research Online is the open access institutional repository for the University of Wollongong. For further information contact the UOW Library: research-pubs@uow.edu.au 


\title{
Towards knowledge management in sports event management: Context analysis of Malaysian biannual games with CommonKADS
}

\author{
Abstract \\ Context Analysis (CA) is typically used as an early phase preceding the development of a knowledge- \\ based systems in order to indicate how the system should interact with its environment and the various \\ stakeholders. We undertake a detailed context analysis of business processes of the Malaysian Games \\ (MG)to highlight blind spots of the process and enable the identification of an initial sports event \\ knowledge management (KM) framework. Firstly, our CommonKADS driven analysis highlights how we \\ can improve the business process and enable the organization to develop, distribute and apply its \\ knowledge resources effectively. Secondly, the paper highlights specific features about the domain of \\ sports events management and accordingly presents a set of recommendations to extend the CA of \\ CommonKADS to improve its applicability to Sports Events Management in general.
}

\section{Keywords}

malaysian, biannual, games, commonkads, sports, event, towards, management, knowledge, context, analysis

\section{Disciplines}

Physical Sciences and Mathematics

\section{Publication Details}

Abdul Ghaffar, A. Rahman., Beydoun, G., Shen, J. \& Tibben, W. (2011). Towards knowledge management in sports event management: Context analysis of Malaysian biannual games with CommonKADS. ICSOFT 2011: 6th International Conference on Software and Data Technologies (pp. 377-383). Spain: SciTePress. Original conference information available here 


\title{
TOWARDS KNOWLEDGE MANAGEMENT IN SPORTS EVENT MANAGEMENT \\ Context Analysis of Malaysian Biannual Games with CommonKADS
}

\author{
Azizul Rahman Abdul Ghaffar, Ghassan Beydoun, Jun Shen and Will Tibben \\ School of Information Systems and Technology, Faculty of Informatics, University of Wollongong \\ Wollongong, NSW 2522, Australia \\ \{arag865, beydoun, jshen,wjt\}@uow.edu.au
}

\begin{abstract}
Keywords: Context Analysis, Knowledge Analysis, CommonKADS, Sports Event Management.
Abstract: $\quad$ Context Analysis (CA) is typically used as an early phase preceding the development of a knowledge-based systems in order to indicate how the system should interact with its environment and the various stakeholders. We undertake a detailed context analysis of business processes of the Malaysian Games (MG) to highlight blind spots of the process and enable the identification of an initial sports event knowledge management (KM) framework. Firstly, our CommonKADS driven analysis highlights how we can improve the business process and enable the organization to develop, distribute and apply its knowledge resources effectively. Secondly, the paper highlights specific features about the domain of sports events management and accordingly presents a set of recommendations to extend the CA of CommonKADS to improve its applicability to Sports Events Management in general.
\end{abstract}

\section{INTRODUCTION}

Knowledge is a fluid mix of framed experiences, values, contextual information and expert insight that provides a framework for evaluating and incorporating new experiences and information (Davenport and Prusak, 2000). It originates and is applied in the minds of knowers. In organizations, it often becomes embedded not only in documents or repositories but also in organizational routines, processes, practices and norms (Davenport and Prusak, 2000). KM is the systematic and explicit management of knowledge related activities, practices, programs and policies within the organization to effectively apply an organization's knowledge and to facilitate the creation of new knowledge to achieve and maintain a competitive advantage (Alavi and Leidner, 2001). In this paper, we investigate how knowledge management (KM) can improve organizing sports events using the biannual Malaysian Games (MG) event as a case study. Organizing this large sports event is knowledge intensive. As many practices and features can be used again in future events, an effective KM strategy promises significant efficiencies.
The MG event is also a fluid domain where location and stakeholders change on a two-yearly basis. The classic problem of 'knowledge walkout' is an inherent characteristic of these KM problems. The significance of this study relates to sport assuming increasing importance in modern and developing economies. Sports events management is a multimillion dollar industry that is growing rapidly. The industry now is important on a global scale economically, socially, politically and technologically. It is widely accepted that the introduction of a knowledge-based system requires change management strategies and additional staff training (Bouarfa, 2008; Swart et al., 2003). This paper applies the context analysis phase of the CommonKADS methodology (Schreiber et al., 2000) to the organization that is responsible for the $\mathrm{MG}$ and provides a roadmap to implement a set of KM policies to improve the current state of affairs and minimize the impact of 'knowledge walkout'. Case study conducted shows how knowledge management is used in sports event management and at the same time reflect the relationship between the domains involved. It will enable the development of sports event management through appropriate strategies. 


\section{KM OPPORTUNITIES IN EXISITING PRACTICES}

The MG is owned and co-organized by the National Sports Council of Malaysia (NSCM); see Figure 1. The NSCM employs a set of policies to implement guidelines to ensure consistency between events and the quality of management. The NSCM aims to provide each of the 14 states of Malaysia the opportunity to host the event. Since it was initiated in 1986, the MG has been held every two years by a different state. The Malaysian Games (MG) can be seen as a smaller scale of a rotating Olympics and the KM constraints will clearly be less than in the management of bigger scale rotating events such as the Olympics.

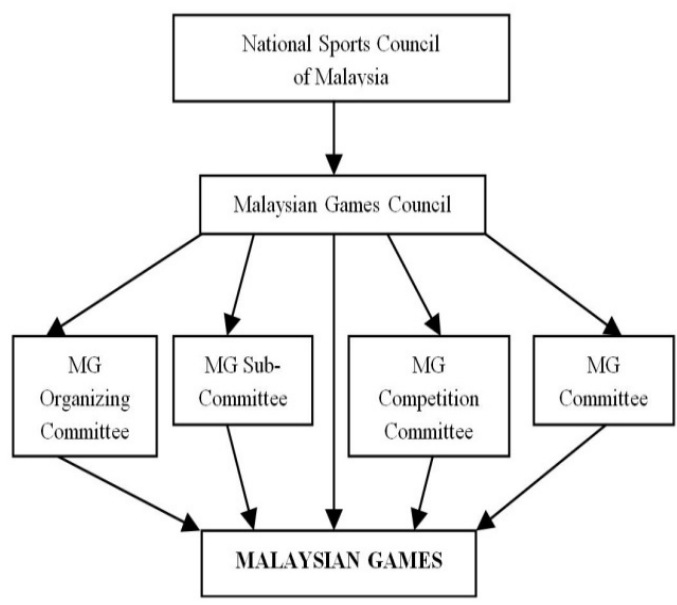

Figure 1: MG Organizing Structure.

The structure in Figure 1 shows the hierarchy of the MG in which there are elements of KM that need to be addressed. CommonKADS has been used as tools in the MG analysis to identify the problems in the MG. KM based observation indicate tacit knowledge in this area. Tacit knowledge is derived from personal experience; it is subjective and difficult to formalize (Nonaka and Takeuchi, 1995). Therefore, tacit knowledge is often learned via shared and collaborative experiences requiring participation and 'doing'. This section describes problems of knowledge loss and contextual problem factors impacting the effective organization of the bi-annual MG in greater detail. We have identified four problems:

\subsection{Duties and Responsibilities are not Sustained (P1)}

Due to the change of host for every MG, nearly 80 percent of staff are new and there is no continuity with previous work. They need to undergo training by the NSCM before performing their duties in their respective departments. The remaining percent of staff, who monitor the operations of each department, are officers of the NSCM.

\subsection{NSCM IT Unit has Overreliance on Outsourcing (P2)}

The development of computer systems is a priority for the MG as it is for most large sports events. The NSCM IT unit has management capabilities but does not have enough manpower to develop the systems. The IT management practice is to engage private companies which require time and additional expertise to become familiar with the existing processes, regulations and requirements of each sport played. The NCSM currently views IT management as a transient role carried out only during the games. The experience of other major sporting events such as the Sydney Olympics suggests this is an area of considerable potential improvement (Halbwirth and Toohey, 2001).

\subsection{Problems related to Ownership of Games Management Systems (P3)}

In the $\mathrm{MG}$, the games management system is the core knowledge source to update users with the latest games news, contingent information, and information on medal tally and record breaking. The hosting state chooses a system based on its own specifications and provisions by the federal government. When the games has been completed, the system becomes essentially state-owned and can not be used by others. The use of the system is not sustained as the host state will not be organizing the next MG and the sports management system is only used in the two weeks of the current organization. The question as to who will be responsible for maintaining the system is always contentious. In addition, the cost of the development of the system increases in every subsequent event because of repeated system development, changes in host committee and IT companies to develop the systems.

\subsection{Overarching Contextual Factor in MG Organization is Lack of $\mathrm{KM}$ Awareness and Practices (P4)}

Knowledge is an important aspect in sports event management. As an example, during the Olympic Games in Sydney 2000, Beijing 2008 and Athens 
2004, the organizers have formed a special committees to manage and store knowledge as a valuable asset for future references. The Sydney Olympic Games in 2000 set up a Post Games Report project for a period of two years. This produced an additional percent increase in data over the year 2000 (Halbwirth and Toohey, 2001). In the MG case, there are no initiatives to encourage those involved to transfer or explicitly codify their knowledge. The officers and staff involved have to learn in an informal way based on the experience of seniors.

Effective management is an important part of successful sporting events at all levels - elite, professional and amateur. This in turn assists sporting organizations to adapt and thrive in an environment of rapid and pervasive economic, social and technological change. Investigating the potential impact of any KM-motivated proposal on an organization is critical for the successful deployment of the future system. Figure 2 shows the relationship between the sub-committees in terms of functions and knowledge flow and the level of knowledge identified during the analysis.

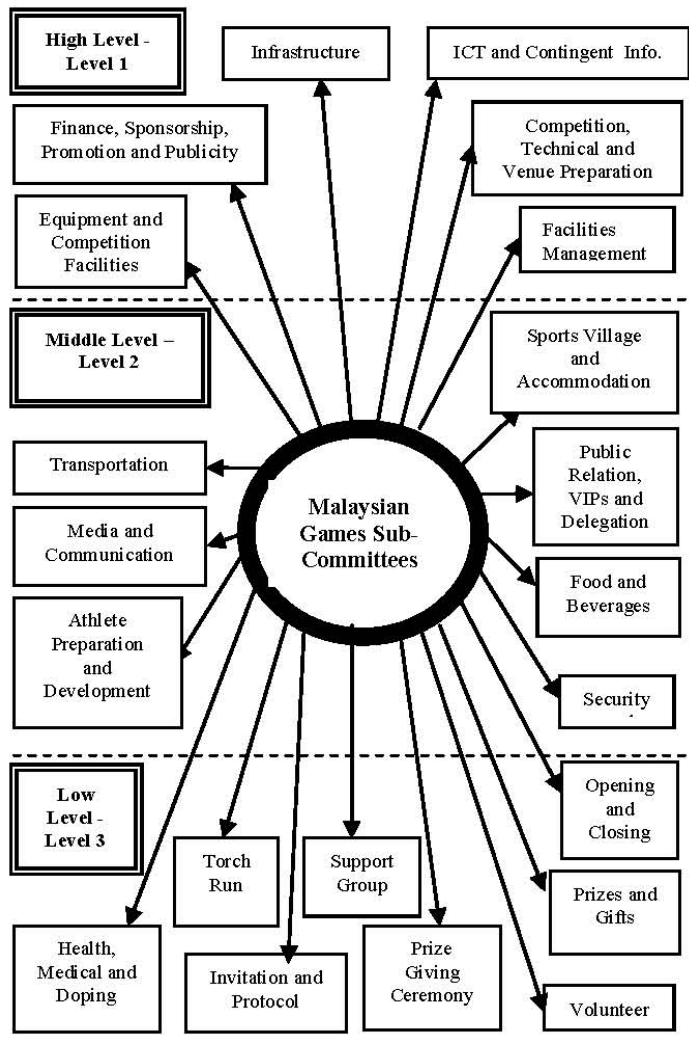

Figure 2: MG Sub Committees (by functions/level).

For this study, sub-committees of the MG were divided into three levels according to the task hierarchy of the MG and the possible strength of KM in its operations. High Level - Level 1 refers to the sub-committee which has the highest level of importance for the management of the MG.

\section{CONTEXTUAL ANALYSIS}

Contextual analysis has been defined as the analysis of the social, organizational and physical environment in which a system will be used (Preece et al., 2002) while Bouarfa (2008) defines context as user, task and physical and social environment. Context analysis is typically used in application development projects to indicate how the system should interact with its environment. Context models describe information and control flow between a system and its environment. According to Aguila et al. (2001), there are many modeling frameworks; the most representative are CommonKADS, MIKE and PROTÉGÉ-II. Each one of them has its own modelling approach. CommonKADS is prominent for having defined the structure of the Knowledge Model (or Expertise Model), MIKE puts emphasis on formal and executable specification of the expertise model, as the result of the knowledge acquisition phase, and PROTÉGÉ exploits the notion of ontology. CommonKADS methodology is a standard in Europe and covers all knowledge based systems (KBS) development processs. CommonKADS provides a complete methodology for the development of a knowledge-based system describing principles, techniques, modelling languages and document structures to assist the construction of a knowledge based systems (KBS).

The CommonKADS offers a detailed sets of models to guide an in-depth analysis. The analysis focuses on the business processes of the organization and traces the use of knowledge in the working processes (Schreiber et al. 2000). CommonKADS methodologies comprises of three phases needed in developing a knowledge based systems (Schreiber et.al., 2000), they are: contextual analysis, conceptual analysis and design. Contextual Analysis in CommonKADS aims to understand the social and physical contexts of organizations to determine their vulnerabilities and potentials by tracking the flow of data through an application, using cross-module, cross-language, semantic and data flow analysis to deliver the most complete understanding of the KM risk.

The CommonKADS organization model supports identification of promising areas for knowledge based systems in organization and detection on how the KBS might affect the organization (Post et.al, 
Table 1: Identifying knowledge-oriented problems and organizational aspects that relate to KM initiatives.

\begin{tabular}{|c|c|}
\hline & ies Worksheet OM-1 \\
\hline & $\begin{array}{l}\text { Identified problems and opportunities in the MG are as follows: } \\
\text { - Duties and responsibilities are not sustained (P1) } \\
\text { - NSCM IT Unit overreliance on outsourcing (P2) } \\
\text { - Problems related to ownership of Games Management Systems (P3) } \\
\text { - An overarching contextual factor in MG organization is the lack of KM Awareness and Practices (P4) }\end{array}$ \\
\hline & 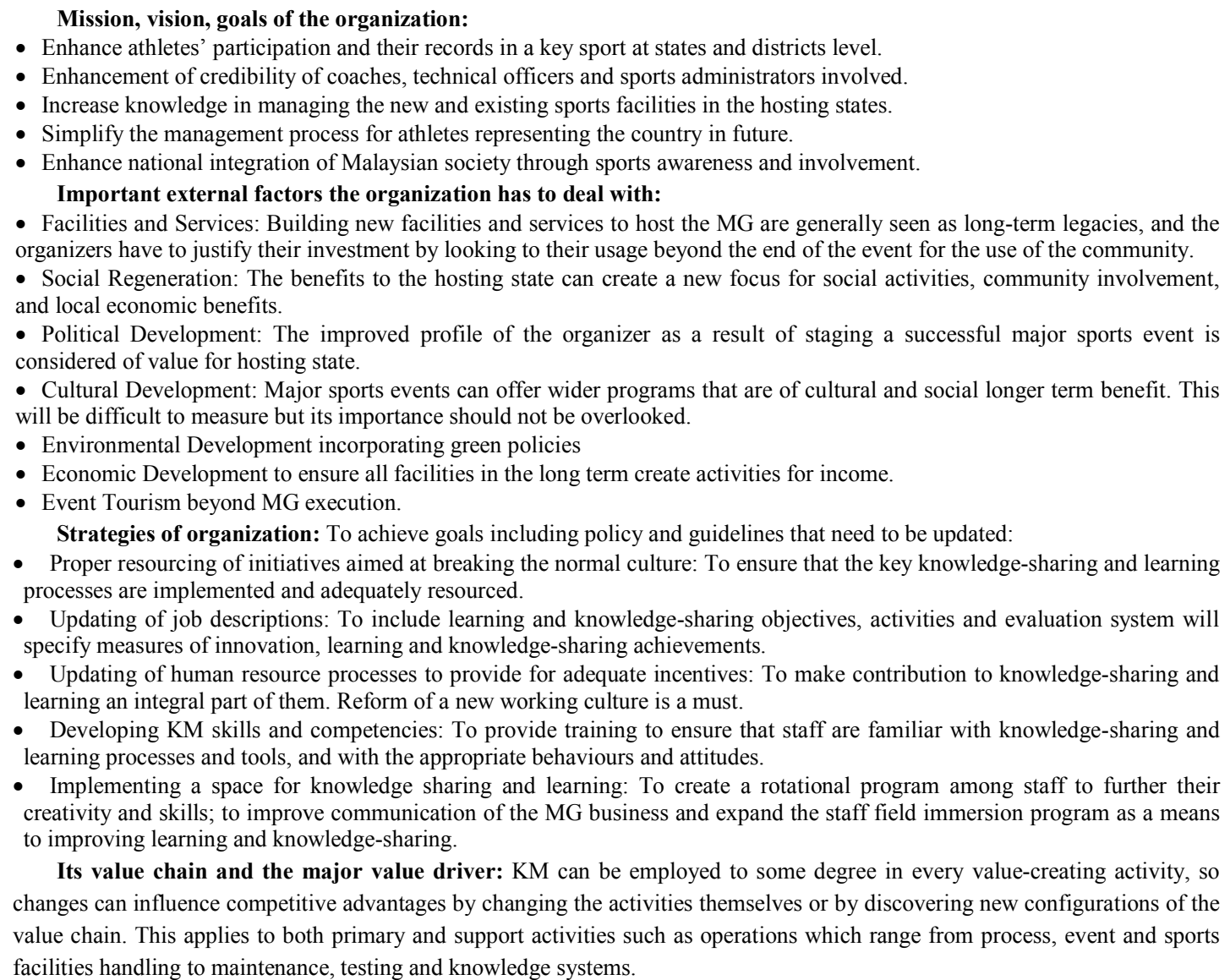 \\
\hline 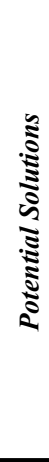 & $\begin{array}{l}\text { - Organizations need more permanent staff, standards, management practices and work procedures. } \\
\text { - Use of systematic workflows and explicit procedures to reduce errors to avoid repetitions of tasks. } \\
\text { - Use of a corporate memory as a basis for viable KM initiatives, e.g. knowledge compilation to support } \\
\text { design, layout and safer products for sports facilities. } \\
\text { - Systematized staff training, planning, organizing evaluation and creating systems for human performance } \\
\text { evaluation. } \\
\text { - Planning for competency and standardization and benchmarking. } \\
\text { - Organizers should reduce the sub-committees to reduce delays and to improve accountability. } \\
\text { To enable technology transfer, all parties involved in IT should be working with IT NSCM Unit. The National Sports } \\
\text { Council's IT unit should have more permanent officers and staff to enable them to plan, and take on the challenge of } \\
\text { introducing KM initiatives. } \\
\text { - To create a repository of so called 'structured knowledge': NSCM should serve as a central database of sports knowledge to } \\
\text { share with involved parties and to meets user needs. }\end{array}$ \\
\hline
\end{tabular}


Table 2: CommonKADS description of the MG organizational aspects that relate to KM initiatives organizational aspects that relate to $\mathrm{KM}$ initiatives.

\begin{tabular}{|c|c|}
\hline & Variant Aspects Worksheet OM-2 \\
\hline$\stackrel{5}{\stackrel{5}{\Sigma}}$ & $\begin{array}{l}\text { The MG Organizing Committee is headed by the Chief Minister of an organizing state. The Committee consists } \\
\text { of the Executive Council and representatives from the state. The Malaysian Games Sub-committee comprising } \\
21 \text { sub-committees set up to operate the MG during this event. Each committee will be chaired by the } \\
\text { representative of the state with their own specific tasks. The National Sports Council Task Force consists of } \\
\text { officers from various backgrounds such as finance, IT, sports management and engineering. The formation of the } \\
\text { group is normally within six month to a year before the games. The states team consists of staff from various } \\
\text { departments of the state. The MG analysis will involve six major sub-committees as follows; } \\
\text { - Finance, Sponsorship, Promotion and Publicity } \\
\text { - Facilities Management } \\
\text { - Equipment and Competition Facilities } \\
\text { - Infrastructure } \\
\text { - ICT and Contingent Information } \\
\text { - Competition, Technical and Venue }\end{array}$ \\
\hline 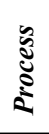 & $\begin{array}{l}\text { The value of sports event organizing is increasingly measured by the way it creates, uses and reuses knowledge } \\
\text { to add value to services and processes, and to improve relationships with users. The organization can use KM to } \\
\text { provide accountability of information and help in decision making processes, together with compliance with } \\
\text { standards by organizing all sources of knowledge available in the MG. }\end{array}$ \\
\hline$\frac{\sqrt{2}}{2}$ & $\begin{array}{l}\text { In the MG management, there are many different people playing many different organizational roles, requiring } \\
\text { very different levels of expertise. Given the brief for the project (OM1), only a very limited area has been taken } \\
\text { into account, mostly the high level committee that is directly involved in some way in the decision-making } \\
\text { process. People will have their roles based on their expertise. Their functions are carried out by full-time staff, } \\
\text { staff on a contract basis or volunteers. They will report to the head of the sub-committee with a specific job } \\
\text { specification for the duration of the games. }\end{array}$ \\
\hline$\underset{3}{3}$ & $\begin{array}{l}\text { The development of KM initiatives for organizing the MG will involve capital, human resources, costs and } \\
\text { physical resources. These may cover different types, such as: } \\
\text { - Information systems and computing resources which provide data capture and storage facilities } \\
\text { - } \quad \text { Facilities, equipment and venues } \\
\text { - } \quad \text { Social, interpersonal, and other (non-knowledge) skills and competencies } \\
\text { - } \quad \text { Technology, patents, broadcast rights in various media outlets } \\
\text { - } \quad \text { Organizing Budget (providing a forecast of revenues and allocation usage of the games) }\end{array}$ \\
\hline 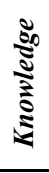 & $\begin{array}{l}\text { Knowledge is a resource exploited in a business process. Sports knowledge, expertise and skills are among the } \\
\text { aspects to be considered. As the MG try to improve the quality of management, it was a straightforward step to } \\
\text { investigate in more detail on knowledge used in variety of ways that can improve the overall performance of the } \\
\text { organization. In addition, as KM initiatives need to be more effective, management should consider knowledge } \\
\text { assets and task-significant perspectives within the sports event management environment. }\end{array}$ \\
\hline & $\begin{array}{l}\text { In } \mathrm{MG} \text {, it is customary to rotate events to vary cultural contexts. This necessitates the need to take a cultural } \\
\text { perspective on the knowledge involved and the concomitant business processes. This view proposes that all } \\
\text { tangible benefits such as stadium, transport infrastructure and tourist facilities, and intangible benefits, such as } \\
\text { sports history making, are accumulated cultural capital. }\end{array}$ \\
\hline
\end{tabular}

1997). For the MG case, the research has been done on six sub-committees (High Level- Level 1 in Figure 2) using the CommonKADS Organizational Model 1 (OM1) - Organizational Model (OM4). Tables 1 - has been used to identify the main problems in the MG organization that requires the use of $\mathrm{KM}$ in the future in strengthening this organization. The focus is on problems, organizational context and the problems solution. Tables 2 - has been used in identifying areas of the organization associated with the KM initiatives focuses on organizational structure, organizational process, people and resources. Tables 3 - has been used to assess and demonstrate the process of covering their daily duties in the organization and the KM-related characteristics. Tables 4 - has been used to demonstrate knowledge of identified component in the organization and specifically relevant to the study. Details of the use of this table is described as follows;

\section{DISCUSSION}

Through this case study has revealed some things that give contribution to the development of knowledge management in sports event management. Whatever the effects occur and have 
Table 3: CommonKADS description of the process in terms of the tasks and their main characteristics.

\begin{tabular}{|c|c|c|l|c|c|c|}
\hline \multicolumn{2}{|c|}{ OM 3 } & \multicolumn{5}{|c|}{ CommonKADS Process Breakdown Worksheet (OM-3) } \\
\hline & Task & Agent & \multicolumn{1}{|c|}{ Where? } & Knowledge Aset & Knowledge Intensive? & Significance \\
\hline 1 & Finance & Accountant & $\begin{array}{l}\text { Finance, Sponsorship, } \\
\text { Promotion and Publicity }\end{array}$ & Tacit skills, Qualification & Yes & 5 \\
\hline 2 & Sponsorship & $\begin{array}{c}\text { Sponsorship } \\
\text { Manager }\end{array}$ & $\begin{array}{l}\text { Finance, Sponsorship, } \\
\text { Promotion and Publicity }\end{array}$ & $\begin{array}{c}\text { Tacit skills,Finance } \\
\text { procedure }\end{array}$ & Yes & 4 \\
\hline 3 & Promotion & $\begin{array}{c}\text { Marketing } \\
\text { Manager }\end{array}$ & $\begin{array}{l}\text { Finance, Sponsorship, } \\
\text { Promotion and Publicity }\end{array}$ & $\begin{array}{c}\text { Tacit skills, procedure } \\
\text { Sports Act 1971 }\end{array}$ & Yes & 4 \\
\hline
\end{tabular}

*(Only some are shown -3 out of 13$)$

Table 4: CommonKADS description of the knowledge component of the MG organizational model knowledge component of the MG organizational model.

\begin{tabular}{|l|c|c|c|c|c|c|}
\hline \multicolumn{1}{|c|}{ Organization Model } & \multicolumn{3}{c|}{ CommonKADS Knowledge Assets Worksheet OM-4 } \\
\hline \multicolumn{1}{|c|}{ Knowledge Asset } & Agent & Task & Right Form? & $\begin{array}{c}\text { Right } \\
\text { Place? }\end{array}$ & $\begin{array}{c}\text { Right } \\
\text { Time? }\end{array}$ & $\begin{array}{c}\text { Right } \\
\text { Quality? }\end{array}$ \\
\hline $\begin{array}{l}\text { Tacit skills, qualification, } \\
\text { finance procedure }\end{array}$ & Accountant & $\begin{array}{c}\text { Finance } \\
\text { management }\end{array}$ & $\begin{array}{c}\text { Yes/new } \\
\text { concept }\end{array}$ & Yes/priority & Yes & $\begin{array}{c}\text { No/depends } \\
\text { on report }\end{array}$ \\
\hline $\begin{array}{l}\text { Tacit skills, finance } \\
\text { procedure }\end{array}$ & $\begin{array}{c}\text { Sponsorship } \\
\text { Manager }\end{array}$ & $\begin{array}{c}\text { Sponsorship } \\
\text { management }\end{array}$ & $\begin{array}{c}\text { Yes/new } \\
\text { concept }\end{array}$ & Yes/priority & Yes & $\begin{array}{c}\text { No/depends } \\
\text { on report }\end{array}$ \\
\hline $\begin{array}{l}\text { Tacit skills, finance } \\
\text { procedure, Sports Act 1971 }\end{array}$ & $\begin{array}{c}\text { Marketing } \\
\text { Manager }\end{array}$ & Promotion program & $\begin{array}{c}\text { Yes/new } \\
\text { concept }\end{array}$ & Yes/priority & Yes & $\begin{array}{c}\text { No/depends } \\
\text { on report }\end{array}$ \\
\hline $\begin{array}{l}\text { Tacit skills, finance } \\
\text { procedure, Sports Act 1971 }\end{array}$ & $\begin{array}{l}\text { Publicity } \\
\text { Manager }\end{array}$ & Publicity program & $\begin{array}{l}\text { Yes/new } \\
\text { concept }\end{array}$ & Yes/priority & Yes & $\begin{array}{c}\text { No/depends } \\
\text { on report }\end{array}$ \\
\hline
\end{tabular}

*(Only a subset is shown- for lack of space)

become the norm in managing knowledge have also been identified and the basis for a decision making process. It shows the situation relating to knowledge management as well as further consideration for the organization. It provides the identification of problems and providing measures to resolve problems. We have identified a comprehensive business process and daily operations of the organization and its relationship with the use of knowledge management. Analysis relating to KM and the MG has never been done before, and we think the use of a reference method to enhance the ability of the organization is required.

\section{CONCLUSIONS}

The MG is a unique case and the model will only be made based on the actual situation in this organization which will be translated into the analysis. CommonKADS through specific templates is able to produce long and inconsistent documentation. Using tables of all documentation makes it difficult and we think the use oftechniques such as modelling of the process and content of the organization far more appropriate and effective. The use of CommonKADS in this analysis can not meet the requirements in the field of sports management in full. Therefore, the sports event management needs its own KM framework that is most accurate and appropriate and is certainly to extend what had previously been done by CommonKADS.

\section{REFERENCES}

Aguila, I. M., Tunez, S., Canadas, J., and Marin, R (2001). A Proposal for Project Management Using CommonKADS. In: Computer Aided Systems Theory Eurocast 2001. Vol. 2178 of Lecture Notes in Computer Science. pp. 160-171.

Alavi, M., and Leidner, D. E. 2001. "Knowledge Management Systems: Conceptual Foundations and Research Issues." Management Information Systems Quarterly (25:1), pp 107-136.

Beydoun, G., and Hoffmann, A (2001). Theoretical basis for hierarchical incremental knowledge acquisition. International Journal of Human-Computer Studies, 54(3):407-452, 2001.

Bouarfa, H. 2008. Designing a Virtual Memory - A Case Study. International Workshop on Advanced Information Systems for Enterprises, Constantine, Algeria.

Davenport, T. H., and Prusak, L. 2000. Working Knowledge: How Organizations Manage What They Know. Boston, MA: Harvard Business School Press.

Halbwirth, S., and Toohey, K. 2001. The Olympic Games and Knowledge Management: A Case Study of the 
Sydney Organising Committee of the Olympic Games. European Sport Mgmt Quarterly, (1:2).

Nonaka, I., and Takeuchi, H. 1995. The KnowledgeCreating Company: How Japanese Companies Create the Dynamics of Innovation. Oxford University.

Post, W., Wielinga, B., de Hoog, R., and Schreiber, G. Organizational Modeling in CommonKADS: The Emergency Medical Service. IEEE Expert 12(6), 97.

Preece, J., Rogers, Y., and Sharp, H. 2002. Interaction design: Beyond human-computer interaction. New York: John Wiley and Sons.

Press conference on cost-efficiency Olympic Games - The Official Website of the Beijing 2008 Olympic Games. http://en.beijing2008.n/live/pressconference/mpc/n214 495413.shtml

Schreiber, G., Akkermans, H., Anjewierden, R., Hoog, R., Shadbolt, N., Velde, W. V., and Wielinga, B. 2000. Knowledge Engineering and Management: the CommonKADS Methodology. Boston, MA: MIT Press.

Swart, J., Kinnie, N., and Purcell, J. 2003. People and Performance in Knowledge-Intensive Firms. Chartered Institute of Personnel and Development, London. 